\title{
Britain: A Suitable Case for Treatment?
}

\section{Stuart Holland}

It is commonplace enough to observe that nineteenth century Britain could not forever maintain her global hegemony. The world's first industrial power was bound to be challenged by the rise of modern industrial economies in the United States, Germany and Japan. Similarly, the contraction of the capitalist world and the collapse of colonialism were events over which Britain had little direct control.

Yet it is not as commonplace to maintain that ex-colonialist countries are bound to irreversible decline. While this may have been the main part of the history of Spain, it has not notably been the case of postwar France or the Netherlands. Both countries have achieved a significant regeneration of their economies in the postwar period, if not emerged phoenix-like from the ashes of the war. Similarly, the three countries which tried-and failed-to establish world empires in the 1930s and early 1940s-Germany, Italy and Japan-have managed in varying degrees to achieve what have been heralded as miracles of modernisation in the postwar period.

Superficially, there would appear to be a correlation between those economies who lostor lost out-during the war and those who won the economic peace. In the case of the main Western European continental countries and Japan, there is some meaning to this. The ideologies of either fascist or collaborationist states were discredited, sleepers were weeded or expelled from national administrations and company boardrooms, and a career opened to those with talent and initiative on a scale not paralleled in postwar Britain. In short, the decks were cleared for reconstruction.

Yet this alone does not explain the dramatically higher rates of reconstruction in Germany, Italy, France and Japan than those in Britain. One factor certainly was the disproportionate share of defence and armaments spending in Britain, relating to her continuing pretension to superpower status, aided and abetted by a United States which was content to see Britain take an excessively heavy share of expenditure for the Korean war. Another, arguably, was the inability of Britain to wipe the slate clean on her wartime debt, and the continuing role which sterling played as a reserve and trading currency on a world scale, subjecting her reserves and exchange rate to pressures of a kind unknown to the other main European economies and Japan. Besides which, put simply, it seems clear that sterling was overvalued through the 1950s, while the Deutschmark was under-valued and the French devalued without notable inhibition.

There were other factors in the relatively low rate of economic growth of the postwar British economy. For instance, while Britain emerged from the war employing just 1 worker in 20 in agriculture, the ratio in Japan, Germany, France and Italy was closer to 1 in 5 or 1 in 4 . In short, the labour reserves from agriculture on which these economies could draw during the reconstruction period were not matched in Britain. These arguments, made familiar recently by Verdoorn and Kaldor, and stemming indirectly from Marx via Kindleberger and Arthur Lewis, are clearly relevant to the case argued for growth with unlimited supplies of labour in the development economics context.

On the other hand, labour availability is not a sufficient condition for either growth or development. This has been clearly illustrated by postwar India, but is also apparent from the situation of the OECD countries today, with their several million unemployed. Nor is high labour availability-either from shifts out of agriculture, or immigration, or both-sufficient to maintain high rates of growth of capital accumulation. For instance, growth of gross domestic fixed capital formation in West Germany fell from an annual average rate of 9 per cent from 1950-54 to 6 per cent in 1960-64 and to less than 1 per cent in $1970-74$, i.e. a dramatic decline before the OPEC oil price rises and the recession of the mid 1970s.

The decline in capital accumulation so frequently overlooked in Germany would be more apparent during the current recession if two thirds of a million guest workers had not found their invitations foreclosed, and returned to their countries of origin during the 1970s. If they had stayed, they would have increased official German unemployment figures by more than half to nearly 7 per cent-the highest level in the EEC and second only to the United States in OECD. By this kind of criterion it could be argued that 
West Germany has exported her costs of failed growth to other countries. Certainly, the supernormal growth rates of the West German economy in the 1950 s, of over 7 per cent GNP expansion per annum had given way to more normal rates of 4.5 to 5 per cent by the early 1970s. Similarly, Italy's rapid rate of growth in the 1950 s, dependent essentially on productivity increases in excess of wages, was checked and reduced in the later $1960 \mathrm{~s}$.

In fact, if there is an economy against whose overall performance Britain compares poorly, it is France, who increased her annual average growth rate throughout the postwar period until the mid 1970s recession. It is arguable that the French showed greater capacity to intervene directly on the supply side of the economy, and match capacity to demand, than successive British governments sitice the war. Yet even in France, crucial strains on the growth process emerged, especially in the 1960s. The Fifth French Plan had scheduled a major allocation of resources to social expenditure on housing, health and education. Yet de Gaulle's government instead concentrated resources on office development, large scale computers, a rocket programme, the nuclear 'force de frappe' and Concorde. Neglect of social factors in the model of growth underlay the 'grave social tensions'-as the authorities themselves euphemistically called them -of 1968, and appear to have contributed substantially to the growing political support for the Common Programme of the French Left, with its commitment to 'a new model of development'.

Besides, while Britain's GNP growth may have been relatively poor for the 25 years following the war, and averaged less than 3 per cent a year, the achievements of the post-war Labour government in establishing the main framework of a welfare state could justify the claim that some of the key objectives of the continental European Left today were secured before the mid century in Britain. The National Health Service is the clearest example. Furthermore, in the 1960s, the expansion of higher education facilities was pursued with vigour-on lines previously blueprinted by the Conservatives-in contrast with its atrophy in France.

Nonetheless, by the 1960 s, it was becoming increasingly apparent that something was wrong. In 1966 the incoming Labour government had promised a better management of the economy than the stop-go cycle of the Conservatives, yet within four months of gaining a major parliamentary majority had introduced a deflationary package bringing about the biggest stop to expansion since the war. This undercut the pretensions of the National Plan of 1965, and with it the assumption that the government was in strategic command of the economy. The 1968 'after-plan', "The Task Ahead", admitted this bluntly stating that "what happens in industry is not under the control of the government".

If the Conservative government from 1970 to 1974 frittered away a trend to balance of payments surplus, the incoming Labour government in 1974 proved itself incapable of implementing new policies for positive intervention in the supply structure of industry, and has cut public expenditure-or its increase-on a scale which made the cuts of the 1960 s look marginal by comparison. It committed itself to a detailed package with the IMF with as little apparent bargaining power as many a less developed country. It is fairly clear that it expects the country's economic destiny to be reversed by North Sea oil. Yet it has mortgaged this oil revenue against foreign debt on a major scale, and shows little evidence that it can take advantage of the relief to the balance of payments offered by oil self-sufficiency to regenerate British industry.

Superficially, it might appear that Britain's economic problem had little to do with development or under-development, and was closer to over-development. But the conventional distinction between developed and less developed countries and the identification of development with GNP performance are unable to explain the unequal dynamics and incidence of development on a global scale. Under-development, over-development, non-development and anti-development are more appropriate terms of reference for analysis. Moreover, the role of non-economic factors in influencing or obstructing development itself have come to be admitted as crucial following the false hopes of many countries in the postwar period. Further, a society in crisis may incorporate disjointed or unsynchronised elements of underdevelopment and over-development in the same social and economic system.

These factors can be illustrated by the issue of industry and the supply structure of the British economy relative to demand management. For much of the postwar period it was part of the textbook basics in development economics that Keynesian policies of demand management were inappropriate for less developed countries because the latter lacked the kind of supply structure which could be 'managed' on the demand side. Thus a good deal of development economics 
focused on supply issues, including in particular the question of balanced versus unbalanced growth of particular sectors of industry, with the debate swinging between the 'big push' case for concentration on certain basic industries, and the 'broad front' case for across-the-board intersectoral development.

In a so-called developed economy such as Britain, issues of industrial structure were relatively neglected in most of the postwar period, such 'micro-economics' being left mainly for maverick academics to research. They could only be analysed statistically by means of a 10-year industrial census in contrast to the monthly or quarterly price, trade output and employment figures of the main Keynesian macro-economic aggregates. This was not simply a matter of accounting, but reflected the extent to which the Keynesian ideology of demand management swept both academic thinking and government policy-making in the post-war period.

Yet in reality, the postwar industrial structure of the British economy has become increasingly imbalanced. The 'big push' from the government side was towards advanced technology and especially defence related industry, including nuclear power, nuclear weaponry, supersonic aircraft and other sophisticated lines of production of questionable income or employmentgenerating potential. Neglect of not only traditional industry, but also the broader range of modern industrial production has now resulted in a profoundly imbalanced industrial structure, with 'de-industrialisation' and chronic contraction in specific areas of industry such as clothing, footwear, heavy and light mechanical engineering, electrical engineering and electronics. Policies of town and country planning and regional development have been partly supply based, but at the level of individual firms and their location rather than the interregional balance of industrial structure. The main thrust of regional policy has been based on a variant of Keynesian demand management policy, assuming that capital and labour incentives both would attract firms to less developed regions and enable existing firms in the regions to lower prices thereby giving them the effect of a regional devaluation relative to the national and international economy.

Commodity and oil price inflation apart, the result in the 1970s has been the emergence of crisis in both economic structure and its spatial distribution in Britain. It is possible to argue that the loss of over half a million jobs in manufacturing is more structural than cyclical, and that the rise of
Scottish and Welsh nationalism, quite apart from a decade of virtual civil war in Ulster, are in part manifestations of the regional disintegration of the UK economy. Besides which, the assumed 'micro-economic' base of the British economy has been transformed in the post Keynesian era by the rise of giant companies which both dominate national economic performance, and have located abroad on a far higher scale than our main international competitors. For instance, whereas the top 100 manufacturing companies in 1950 accounted for about a fifth of manufacturing output, they now represent about a half of such output, half of manufacturing employment, more than half of industrial assets and visible export trade, and the main part of the price determination in the economy. These firms represent less than 1 per cent of the total number of enterprises in the UK economy, yet account for more than half of economic activity.

This is a far cry from the supply structure of the 1930s. Its multinational dimension also has major implications for Keynesian exchange rate policy. All of the top 100 manufacturing companies are to a greater or lesser extent multinational in operation. But the general degree of multinationalisation of the British economy is way in excess of our leading international competitors such as Germany and Japan. In fact, the value of foreign production by British business operating abroad is more than five times as high as German or Japanese business and represents more than twice the value of total UK visible exports, in contrast with less than two fifths of national exports by German and Japanese companies operating abroad. This vast structural disproportion, compared with such other countries, may be one of the main reasons for the stubborn unresponsiveness of UK exports to devaluation. When leading British businesses operate abroad on such a scale, they become their own competitors in key foreign markets, having less incentive to lower export prices in line with devaluation, since this would lower the price for goods they or their subsidiaries already produce.

Put differently, there is a strong case for maintaining that the British economy now is dominated on the supply side by a handful of giant enterprises which represent a new 'meso-economic' sector in between the conventional Keynesian wisdom of macro-micro distinctions. The same in fact is true of the Japanese economy on the domestic production side, if not to a greater extent, with a closer integration of finance and industrial capital. Also, French planners have been aiming for 20 years at an industrial structure 
in which 20 per cent of enterprise would account for 80 per cent of output in any given industry, and now have achieved a ratio whereby some 2 per cent of enterprises command 80 per cent of output overall. The difference between Britain on the one hand, and Japan and France on the other, lies substantially in the ideology, influencing government policy formation on the supply side. In both Japan and France, meso-economic policy has ante-dated meso-economic theory. Governments have sought closer and better defined relations between the State and the big business which dominate the economy. In Britain, the mythology of a liberal capitalist competitive framework still dominates government policymaking.

These trends have become particularly evident in Britain of the 1970s. In the opening years of the decade, the Conservative government attempted a Keynesian Indian summer, boosting demand on a massive scale in an attempt to break through to sustained growth on the supply side of the economy. They failed to take account of the extent to which big business had already come to dominate the economy. They thereby ignored the manner in which forward planning by big business now spans a time horizon not only longer than annual budgets, but longer than the political lifetime of most governments. Similarly, Labour governments since 1974 have chosen to disregard the new power structure of big business in their own party policy programmes, and have attempted to run the economy without a mesomicro policy distinction. They have also failed to understand the extent to which the 'new inflation' of the later 1960 s and 1970 s not only reflects the raised unit costs of enterprise in the post 1974 recession, but also the price making power of big business. The latter is encouraged to raise prices to compensate for lost cash flow during recession so long as governments do not reflate demand, and it is able to do so because the latter do not impose a framework of price controls on leading enterprises based on more effective information about their real cost and profit structures.

This neglect of the supply structure of the economy in Britain. in contrast with the preoccupation with supply in less developed economies, relates also to the increasing paradox of the 'dependent development' (or non-development) of Britain. With the rise of the US, German and Japanese economies from the end of the 19th and early 20th century, it was inevitable that British economic hegemony on a global scale should be successfully challenged. But the marked decline since the war in Britain's economic standing in both the international economy, and the international economic community, has not just been a matter of the relative increase in global market share of other economies, nor of the problems of sterling as a reserve and trading currency in a period when the 'losers' from the war wiped the slate clean and developed with restructured national currencies. It lies substantially in the neglect of supply factors underlying the failure of the planning experiments in Britain from the introduction of the National Economic Development Councils and the 1965 National Plan, to the resistance by the post-1974 governments to implementing the new dimensions to planning offered by the Labour Party.

This is illustrated by the contrast between the restrictions on public expenditure following the 1976-7 IMF loan and the massive public subsidy of the private corporate sector freely undertaken by the post-1974 Labour government. The dualism in British industrial structure between large-scale multinational capital and smaller scale national capital is associated closely with dual profit levels between big and small businesses. By and large, while size certainly is not a sufficient condition for competitive success, economies of scale, not only in production and distribution but also in access to favourable large scale finance, hold over buyers and suppliers, brand attachment, etc.plus the price 'making' power which comes from size, has enabled large-scale capital in Britain to maintain significant profit levels through the 1970s. Smaller scale capital, lacking such advantages and subject to price 'taking' from the consumer, whether inter-firm buying or final purchases, has not managed to maintain such profit levels in a period of commodity, oil and intermediate goods inflation. Yet the government, in one measure alone-tax relief on stock appreciation-gave a new form of rebate to the private sector equal to some $f 3.8 \mathrm{bn}$. after 1974 , more than the total amount of the IMF loan itself. Overall, in addition to the broad range of rebates on nominal tax, including especially depreciation allowances, but also investment grants, $R$ and $D$ write offs etc., it can be argued that the big league private sector company either is not paying any effective corporation tax, or should not be doing so if it employs a competent accountant within the framework of the existing legislation.

Put starkly, this represents a situation in which the British government has shown itself incapable of harnessing the strong points of the British economy in order to bring about a planned expansion of investment, output, productivity and 
incomes. As a result, rather than the virtuous circle assumed to be feasible for developed economies, the UK has been caught in a classic vicious circle of stagnant overall investment, structural unemployment, and depressed expectations and demand depressed further by the cutback in public expenditure. The fiscal crisis in Britain has been a consequence partly of lost tax receipts from personal and corporate income (with falling unemployment and stagnant demand) but also of the basic failure of the State to tax the most powerful, potentially productive sections of the economy: the big business leaders. Welfare expenditure either has been cut, or financed through raising public sector borrowing, or covered through increasingly regressive personal taxation.

The combination of structural crisis in export trade, in productive investment and in the tax system has of course been traumatic for those in the Labour movement who had come to assume that rising real public expenditure could be financed through rising real personal and corporate incomes. The combination of stagnating investment, rising unemployment and inflation, which should not occur in the postwar application of the Keynesian or neo-Keynesian paradigm, opened the way for Friedman and monetarism to fill the apparent void in Keynesian policies. Yet Friedmanism, and the philosophy of cutting both public expenditure and the welfare state framework, if pursued indefinitely, would be likely to open still further the acute social and economic divisions in British society.

It is widely recognised that oil alone will not salvage the British economy. Worse, the dramatic impact of oil self-sufficiency on the balance of payments may temporarily disguise the nature of the fundamental structural changes in Britain, and make it possible for a government in power in the late 1970s and early 1980 s to squander the opportunity to use the breathing space from oil to restructure policy and the machinery of policymaking in order to bring about the regeneration of Britain. Britain will be the only major oil producer in the world which is also a major industrial power. Also oil is now backed by the new coal fields, with resources on a scale which economies such as Japan and France, without fuel reserves on a major scale, could well envy. Yet both Japan and France, in the postwar period, have exploited their intellectual and organisational resources in such a way as to overcome their lack of economic resources per se. Britain at present shows no such capability.

If Britain is to transcend the current crisis and transform its economy it will need to do so by a conscious focus on development rather than growth, and through a major attempt to refashion the pioneering vision of the Welfare State to make it relevant to challenges of the remaining decades of the century. The full employment criteria of the postwar period will need redefinition in such a way as to establish rights both to equalised employment hours and to equalised incomes. Social income based on increased social services will have to be established at the heart of the political process as a right rather than a concession. The social relations of production will have to be democratised in the form of workers' control of the labour process. Such an extension of workers' control is perfectly compatible with the technical complexity of modern economic society, provided that essential macro-economic priorities are planned in the pace-making in the meso-economic sector. Social justice in the personal and regional distribution of employment, income and wealth will have to be confronted in a manner unparalleled in the last quarter century.

This is a challenge for which the British labour movement, as opposed to the government, is potentially well placed. But if the advance is to be achieved, it will demand a democratisation not only of the general use of resources in society, but also of the political process including the relationships between party and government in office. It would require more open government, at both national and local level, with an increased devolution of decision-making at the regional level. This would involve not only a reform of the outdated Official Secrets Act, but also increased accessibility for community and other pressure groups to the data with which government policies are formulated; it also should involve greater tactical control by regional and local bodies over the implementation of strategic national policies. Such policies would amount to a major reversal of the present concentration of nominal power in central government. But they might increasingly be a condition of the exercise of effective power by governments, based on extended public debate and consent, rather than the present crisis situation in which governments take office without the capacity to exercise effective power.

The new policies may also demand some adjustment to the at present highly unequal mix in the public and private sectors of the economy. In effect, while public expenditure now accounts for more than half of total spending, public enterprise represents less than 15 per cent of the contribution to GDP. The demand and supply sides of the 
public sector, in this sense, are highly imbalanced. It is private enterprise, and especially enterprise in the monopolistic multinational sector, which dominates the manufacturing industries of the economy-those which the French appropriately call the 'transformation' industries.

If a new public sector on the supply side is to avoid the bureaucratisation and deadening hand of central government inertia, it will need to incorporate several modes of public ownership, including central government, local and possibly regional government, cooperative ownership, and community development projects. In some cases, it could involve several such modes on a joint venture basis, with variable joint ventures with private sector enterprise and initiative. Such an approach to a more genuinely mixed economy need be neither sudden nor centralised. To prove successful in releasing the initiative and involvement of working people in society. it should be gradual and progressive. But its extension nonetheless should be decisive if the new dimensions for a social mode of development, in consumption and democratic control, are to be matched on the supply side of the economy which has been so neglected during the Keynesian era.

The new planning made possible by a re-mix in the ownership and social control of the supply side of the economy should be focused on harnessing and transforming the criteria for use in the dominant meso-economic sector. In this sense, Planning Agreements, jointly negotiated by government, unions and management, should be used not simply to attempt to make the prevailing economic structure work at higher levels of efticiency, but also to change the use of resources in society. In this sense, a new mode of development based on social criteria should be brought to the centre of the process of political debate. It should involve the feasibility of changing the potential growth rate, and the manner of development, rather than simply estimating the potential growth of the system by present private criteria and technical factors in the manner of Keynesian or Harrod growth models (such as underlay much of the reasoning of the National Plan). The objectives for most working people are clear enough-they are the conventional postwar objectives of the Welfare State: decent housing, health facilities, education, transport, conditions at work, personal income and leisure.

The feasibility of achieving such objectives is greater than before, provided the economic criteria of the leading enterprises in the system-and especially the top 100 companies-are related to the ends of a social and socialised model of development. This would include constraints on unlimited foreign expansion by British based capital, and a closer planned linkage between supply structure and the new socialised demand patterns. The chronic imbalance and disproportion of foreign investment--substituting substantially for visible exports-may not be a priority for governments taking a short term perspective during the coming years in which oil makes Britain self-sufficient in key fuel needs. But it is crucial that the capacity to establish strategic government control over leading enterprise in the meso-economic sector is secured in the coming period of oil abundance. Otherwise, Britain will neglect the lesson underlying the oil price rises in the 1970s: i.e. the fact that OPEC countries looked ahead to their prospects 'after oil', and realised that they had only two to three decades in which to assure the base for autonomous, non-dependent development. 